\title{
The power of forgiveness in a broken world: An understanding of forgiveness in Ephesians
}

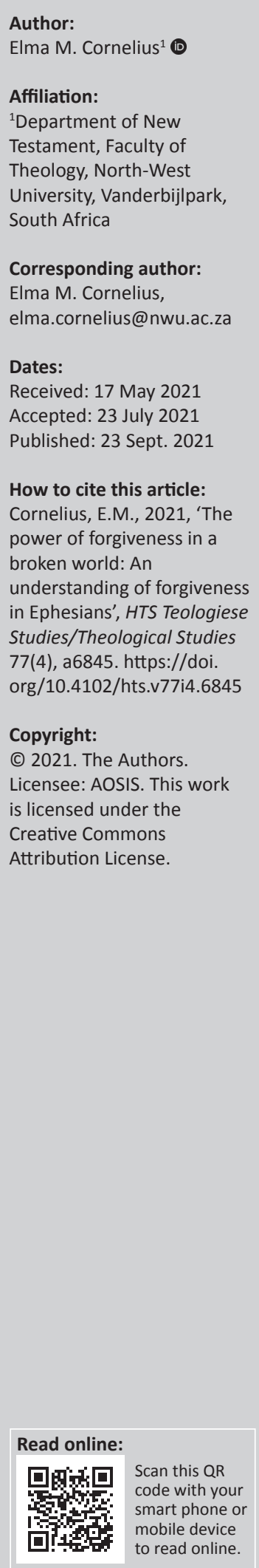

South Africans live in a broken country where hatred leads to violence and destroys the relationships between people. The pertinent question here is: Is forgiveness between South Africans possible? This article is an attempt to understand 'forgiveness' in Ephesians, and to discuss the power of such forgiveness in a violent and broken South Africa. Ephesians 4:23 demands a change in the people's mindset in order to be able to, inter alia, be kind and compassionate when they forgive each other (Eph 4:32). This forgiveness means to take control as a believer and to use one's power as a Christian to forgive because God forgave us. We need to be the initiators of the transaction. Forgiveness is a 'means for imitating God', for 'carrying out God's plan', and 'enhancing one's relationship' with God. Forgiveness will restore relations; it is a gift to oneself and to others, to society, to one's country. Ephesians advises to no longer rehearse and re-think the memories of pain, to stop harbouring and nursing grudges, to stop playing the victim and perpetuating negative emotions associated with this rehearsing, and to break people's commitment to remain angry.

Contribution: Ephesians aims to persuade believers that forgiveness is a choice to imitate God. Forgiveness is an act out of grace, kindness, and compassion.

Keywords: forgiveness; Ephesians; South Africa; choice; grace; kindness.

\section{Introduction}

South Africa today has one of the worst crime rates in the world (Baxter 2020; The Globalist 2018). It is said that the murder rate is worse than the COVID-19 mortality rate even in these turbulent times (Gibson 2020). Currently in South Africa, the main concern is the murdering of farmers, and more so as this situation is 'racially motivated' (Zulu 2020). Is this happening because South Africa has millions of damaged and wounded people? Some say these wounded people are the legacy of apartheid (Smith, quoted by Nkosi 2018). The Centre for the Study of Violence and Reconciliation (CSVR) reported (see South African Government News Agency 2010) that:

It may be a policy of the past but the evils of apartheid continue to haunt the country, emerging as one of the key contributors to the high level of violent crime in South Africa. (n.p.)

The Nelson Mandela administration created the Truth and Reconciliation Commission in 1995 to help South Africans come to terms with their extremely troubled and violent past. But all is not forgiven, writes Msimang (2018). The scars of apartheid still linger and motivate young black South Africans, who never even lived in the apartheid era, to put the blame for their actions on apartheid. They consider themselves to be disadvantaged by the initiators of apartheid, and blame the white South Africans, who they believe are the beneficiaries of apartheid, for all their problems. These actions, however, continue to create more opportunities for hatred by the white South Africans against those black people who grab land, murder, and destroy out of hatred. As a result of this vicious cycle of hatred amongst different races grows every day, and what we see is a broken country, heading for disaster. Why can South Africans not move on?

'Is forgiveness between Black and White South Africans really possible after more than two decades of democracy?', asked Dr Dion Forster (Head of the Department of Systematic Theology and Ecclesiology at Stellenbosch University) at the fifth Stellenbosch Forum Lecture held on 21 September 2017 (Corporate Communication 2017). Forster (2020:51) writes about the (im)possible politics of forgiveness in South Africa.

This article is an attempt to understand 'forgiveness' in Ephesians, and to discuss the power of such forgiveness in a broken South Africa where hatred continues to destroy South Africans. 
In the interpretation of $\chi \alpha \rho \imath \zeta o$ $\mu \varepsilon v o r$ (while/when forgiving) in Ephesians 4:32, this concept of forgiveness will be studied in the argument structure, in the particular letter-part, in the letter-genre, as part of rhetorical persuasion strategies, against the socio-historical background of the text, with the incorporation of psychological insight into forgiveness.

\section{An understanding of 'forgiveness' in Ephesians 4:32}

'Forgiveness' as a Christian virtue, is mentioned in Ephesians 4:32 ( $\alpha \rho \iota \zeta o ́ \mu \varepsilon v o r ~ \varepsilon ́ \alpha v \tau o \tilde{\varsigma}$ 'while/when forgiving each other'). Before attempting to interpret the meaning of forgiveness as a virtue, it is important to be clear about where this virtue is mentioned in the structure of the letter.

\section{'Forgiveness' in the structure of the letter to the Ephesians}

In the letter-structure of Ephesians (see Table 1), forgiveness (4:32) fits into the letter-body-middle in the second exhortation (4:17-5:21), which is an exhortation to the readers to live as children of the light.

\section{'Forgiveness' in the argument of 4:17-5:21}

The argument structure has been outlined in Figure 1.

In the exhortation in $4: 17-5: 21$, the readers are warned to no longer live as the Gentiles do (4:17), and it is further explained in: 5:1-2 when the author commands them to be imitators of God and to live a life of love; 5:8 elaborates with the imperative to live as children of the Light; 5:11 further explains with the command to have nothing to do with the deeds of darkness. It is concluded with the exhortation in 5:15-15 to be careful how they live. One can thereby summarise the exhortation of 4:17-5:21 as 'do not follow the Gentiles - rather follow God'.

TABLE 1: Letter structure of Ephesians.

\section{Letter-opening: 1:1-23}

Author (1:1), Recipient (1:1), Greeting (1:2), Doxology (1:3-14), Thanksgiving (1:15-23)

Letter-body

Letter-body-opening:

Argument 1: Sinfulness and salvation 2:1-10

Argument 2: Peace and unity 2:11-22

Argument 3: Paul is a preacher to Gentiles 3:1-13

Prayer: 3:14-21

Letter-body-middle:

Exhortation 1: live a life worthy of your calling 4:1-16

Exhortation 2: live as children of the Light 4:17-5:21

Exhortation 3: exhortations to wives and husbands 5:22-33

Exhortation 4: exhortations to children and parents 6:1-4

Exhortation 5: exhortations to slaves and masters 6:5-9

Exhortation 6: put on God's armour 6:10-18

Exhortation 7: live a life worthy of your calling 4:1-16

Letter-body-closing:

Last requests 6:19-20

Letter-closing

The coming of Tychicus, final greeting, benediction 6:21-24
From the outline of the structure of the exhortation, it becomes clear that the motivations for this command to rather follow God than the Gentiles, and to rather live in God's light and be his imitators, are the following:

- The Gentiles are darkened in their understanding and are separated from God; they are ignorant because of the hardening of their hearts; they have lost all sensitivity and have given themselves over to sensuality and impurity, resulting in a continual lust for more (4:19).

- Christians know Christ differently as they were taught to put off the old self $(4: 20)$, to be made new in the attitudes of their minds and to put on a new self (4:20-24).

- The fruit of the Light are goodness, righteousness, and truth (5:9).

- God's light makes everything visible (5:12-14).

Out of the complementing exhortations to rather follow God than the Gentiles, to be imitators of God and live a life of love, and to be careful how one lives, three lists of exhortations may be followed in the furtherance of the moral conduct: the list in 4:25-32, the list in 5:3-7, and the concluding list in 5:17-21. These moral exhortations serve as guidelines for Christian readers in their way of living. By being obedient to these commands, they will be obedient to 'living in the light of God'.

Why would Paul exhort his readers to live in the light of God? Why would Paul also address 'forgiveness' in one of the list of virtues? Was there a 'historical reason' behind the letter in order to exhort them to live in the light of God and to address 'forgiveness'? Scholars are aware of the dispute about the authorship of Ephesians. Fowl (2012:9-28) has a detailed discussion concerning this dispute. The author identified himself as Paul, the apostle, in the letter-opening (1:1). In the dispute on authorship, scholars argued about whether the author was indeed Paul or was perhaps a follower of Paul. In line with the focus of this article, the question will rather be whether or not there are any hints in this letter about why this author needed to address 'forgiveness'. The letter, however, gives no indication of a history between the author and his readers, 'the saints in Ephesus' (1:1) or the background of the readers. Scholars agree that the letter to the Ephesians is a circular letter as it does not reveal the occasion of its writing and it was addressed to various churches in the area of Ephesus, which was most probably not written in response to a particular circumstance or controversy (Fowl 2012:29; Gundry 2012:461).

Paul, however, motivates this exhortation in 5:9 to live in the light of God with the words 'the fruit of the light consists in all goodness, righteousness and truth'. Paul wants his readers to live in goodness, righteousness, and truth. God's light will thus remove all darkness and their behaviour will prove them to be children of the Light. Paul refers to the darkened understandings of the Gentiles - that they are 


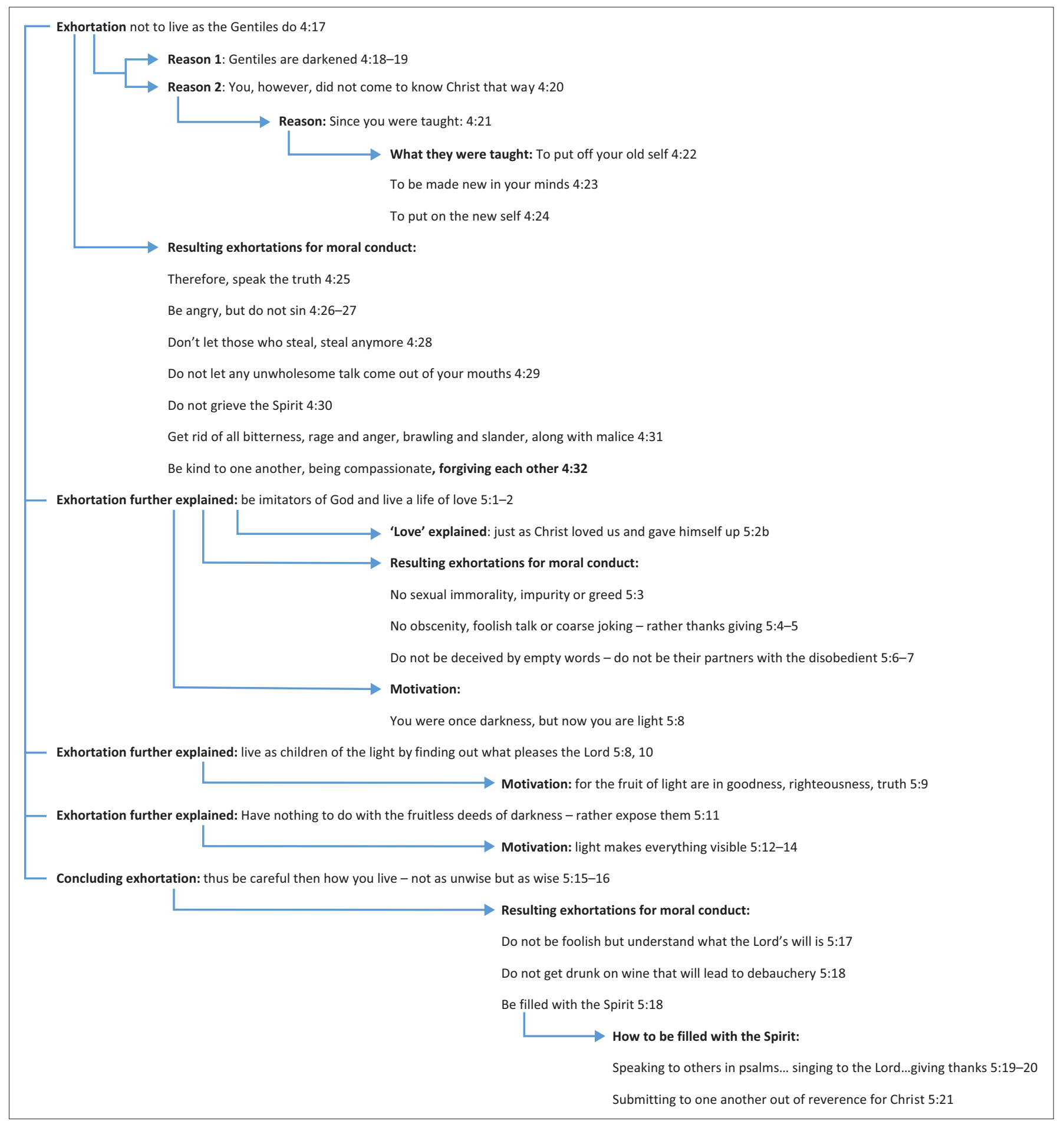

FIGURE 1: Structure of the argument in 4:17-5:21.

separated from God (4:18), and this is the same thought we find in 1 John 1:5, 'God is light; in Him there is no darkness at all'. God's light is the key to our lives. Jesus warned the crowds (according to Jn 12:35) that the man who walks in the dark, will not know where he is going. Darkness makes life miserable, makes humankind hopeless, and unwise (see Eph 5:15).

Paul reminds his readers that they on the other hand, were taught to leave the darkness and to adopt a new attitude in their minds - to change the nature of their minds, to be made

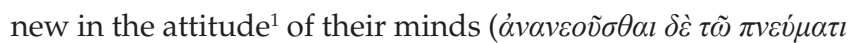

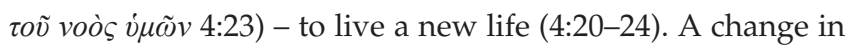
attitude and thinking will thus lead them to be wise (5:15).

The lists of exhortations for moral conduct that flow out of the exhortation to live in God's light, are given to guide the readers in their behaviour. Paul guides readers in order to in which a person thins about or deals with some matter' (eds. Louw \& Nida 1988:350). O'Brin (1999:330) said that the sphere of the (eds. Louw \& Nida 1988:350). O'Brien (1999:330) said that the sphere of the renewing work is a person's 'inmost being' and it means that the 'pattern, motivation and direction' of one's thinking needs to be changed. 
help them to avoid the miserable, hopeless and unwise darkness, and to be imitators of God (5:1).

It is interesting to note that the first list of exhortations for moral conduct in 4:25-32 aims at repairing and enhancing relationships. For relationships to be healthy, one needs to speak the truth $(4: 25)$, one needs to be careful not to sin because of anger (4:26-27), avoid stealing (4:28) and unwholesome talk (4:29), stop grieving the Holy Spirit (4:30), avoid bitterness, rage, anger, brawling, slander, and malice (4:31), and forgiveness coupled with kindness and compassion (4:32), is important.

Fowl (2012:158) explained that 'grieving the spirit' is about 'resisting' the Spirit and resisting God's purpose with one's life. Fowl could be right that this command not to grieve the Spirit, refers back and includes all the previous commands in this list, namely the practices of falsehood, theft, and abusive speech.

Verse 31 follows with behaviour that belongs to the darkness: bitterness $\left(\pi \imath \kappa \rho i \alpha^{2}\right)$, rage $\left(\theta v \mu \grave{o} \varsigma^{3}\right)$, anger $\left(\dot{\delta} \rho \gamma \grave{\eta}^{4}\right)$, screaming $\left(\kappa \rho \alpha v \gamma \eta^{5}\right)$, abusive speech $\left(\beta \lambda \alpha \sigma \varphi \eta \mu i \alpha^{6}\right)$, and every form of badness ( $\sigma \grave{v} v \pi \alpha \dot{\sigma \eta \eta} \kappa \alpha \kappa i \alpha$ ). These are all characteristics that do not speak of love or light and destroy relationships between people. These behaviours hurt people and creates enemies. Putting these vices away, Fowl (2012:159) says, 'is crucial to walking in a manner worthy' of their calling - their calling not to behave like the Gentiles, to imitate God, to walk in His light. This kind of behaviour mentioned in verse 31 , seems to be seen by the author as the opposite of kindness and compassion in verse 32 (see Bray 2011:363).

The exhortation in 4:32 is introduced with the conjunction $\delta \dot{\varepsilon}$. In this verse, the readers are exhorted to rather:

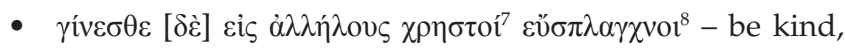
and compassionate

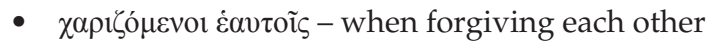

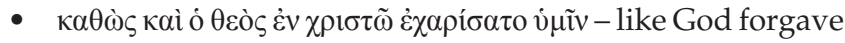
you in Christ.

The conjunction $\delta \dot{\varepsilon}$ in verse 32 appears in the Greek text in brackets, indicating that this conjunction 'may be regarded as part of the text, but that in the present state of New Testament textual scholarship this cannot be taken as completely certain' (see eds. Aland et al. 1994:2*). If this conjunction is taken to be part of the text, one needs to keep in mind that it is most

2.

$3 . \vartheta u \mu o$ c - intense anger with the implication of outbursts, anger, fury, rage, wrath (eds. Louw \& Nida 1988:762).

4.ópyr̀ - anger or fury (eds. Louw \& Nida 1988:761).

5.краuүウं - cry, shout, scream (eds. Louw \& Nida 1988:399)

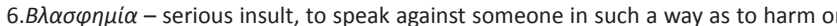
injure his or her reputation, to blaspheme (eds. Louw \& Nida 1988:434).

7.Louw and Nida (eds. 1988:750) to act 'kindly' or be 'gracious'.

8.Louw and Nida (eds. 1988:295) to be 'affectionate' and 'compassionate'. often used to delineate, and slightly contrast. ${ }^{9}$ A clause or sentence from the one that precedes it. Accepting [ $\delta \grave{\varepsilon}]$ to be part of this text, one can therefore interpret this verse as 'rather than destroying relationships through bitterness, be kind and compassionate when you forgive others'. It would mean that on the one side of the coin, Paul exhorts the readers to be kind and compassionate when they forgive, and on the other side, he exhorts them to refrain from bitterness. Fowl (2012:159), however, does not agree with this. He says the virtues listed in verse 31 are not the antitheses of the vices in verse 32 . It seems as if he interprets the $[\delta \grave{\varepsilon}]$ as indicating that we are confronted here by vices that are destructive to common life on the one hand (verse 31), and virtues essential to life (verse 32) on the other hand. In Fowl's mind the parenthesis is thus between 'virtues that can destroy relationships between people' and 'virtues that can save relationships'. When one considers the motivation and typical behaviour of unforgiving people, however, it seems as if the 'bitterness' of verse 31 is indeed the antitheses of 'kindness' and 'compassion' when 'forgiving' (see paragraph3). Ephesians seems to communicate that forgiveness is 'a means of breaking apart cycles of bitterness $(\pi \imath \kappa \rho i \alpha)$, rage $(\theta v \mu \grave{o} \varsigma)$, anger $(\dot{\delta} \rho \gamma \grave{\eta})$, screaming

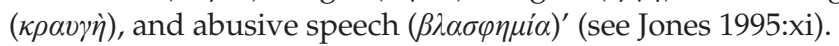

The command in verse 32 is not to 'forgive'. It is almost as if Paul takes it for granted that his readers would know that they need to forgive. Rather, what he emphasises is that readers need to be kind $\left(\chi \rho \eta \sigma \tau o i^{10}\right)$ and compassionate $\left(\varepsilon \nu \sigma^{\prime} \pi \lambda \alpha \gamma \chi v o l^{11}\right)$ when they forgive. The ' $\chi \rho \eta \sigma \tau o i^{\prime}$ in verse 32 is also an attribute of God. This same kindness is referred to in 2:7 in the first argument of the letter-body-opening where the kindness $(\chi \rho \eta \sigma \tau o ́ \tau \eta \tau \iota)$ of God is mentioned as something that followed from his grace ( $\tau \tilde{\eta} \varsigma \chi \alpha \dot{\alpha} \iota \imath o \varsigma \alpha \dot{\tau} \tau o \tilde{v})$. Fowl (2012:160) shows that Paul clearly sets the standard for the expected kindness as he uses the same word in 2:7 when he writes about the 'kindness' of Jesus Christ. God's kindness to the Ephesians (referred to in 2:7) serves as model for kindness as commanded in 4:32. The implication is that if the Ephesians can show kindness, they will be considered to be imitators of God (see 5:1). Bray (2011:363) describes this kind of kindness as something that will never flourish in believers without compassion ( $\varepsilon \tilde{\sigma} \sigma \pi \lambda \alpha \gamma \chi v o r-4: 32)$ - something that will affect everything the believer does or says. This compassion, Swindoll (2015:260) says, is tender-heartedness. The moment one forgives thusly, God's attributes of kindness and compassion show in one's behaviour and one is proved to be an imitator of God - living in his light. The 'kindness' is not a natural or self-produced ability, says Hoehner (2002:638), but it is a fruit of the Spirit as explained in Galatians 5:22. O'Brien (1999:351) reminds us that the word for 'compassion' is also used in the New Testament ${ }^{12}$ to describe God or Christ. The author of Ephesians thus wants godly behaviour from his readers (see Cohick 2005:117), when they forgive others.

9.Moulton (1978:85) describes the function of this conjunction as 'marking the superaddition of a clause, whether it is in opposition or in continuation to what has sued'. See Hoehner (2002.637) about a contrast 'marked out by the adversative $\delta \varepsilon^{\prime}$ and see Funk (1961:231) for a discussion of adversative conjunctions.

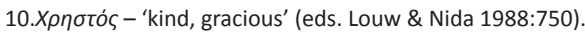

11.Eü $\sigma \pi \lambda \alpha \gamma \chi v o \varsigma$ - 'compassionate' (eds. Louw \& Nida 1988:295).

12.See Matthew 9:36; 14:14; 18:27, Luke 1:78; 7:13; 10:33; 15:20. 
The participle $\chi \alpha \rho \imath \zeta o \mu \varepsilon v o l$ is in the present tense. Although participles originally had no temporal function (See Funk 1961:174), the present participle was sometimes interpreted to indicate that the action of the participle happened at the same time the actions of the main verbs happened (See Conradie et al 1999:248). Thus, out of forgiveness, kindness and compassion will automatically flow.

The participle $\chi \alpha \rho \imath \zeta o$ $\mu \varepsilon v o r$ has the meaning possibilities of 'to give or grant graciously and generously' (eds. Louw \& Nida 1988:569), 'to release a person from the obligation of repaying what is owed' (eds. Louw \& Nida 1988:582), 'to hand someone over into the control of another person' (eds. Louw \& Nida 1988:475-476), and 'to forgive on the basis of one's gracious attitude toward an individual' (eds. Louw \& Nida 1988:503). Hoehner (2002:639-640) prefers the translation of 'being gracious' because he is of the opinion that 'graciousness is the antithesis of bitterness, anger, wrath, shouting and abusive speech' in verse 31, and that graciousness is much broader than forgiveness, although it does include forgiveness. When one considers, however, the process of forgiveness, it seems more acceptable to think that forgiveness is the process through which one gets rid of all the negative emotions and actions in verse 31. O'Brien (1999:351), therefore, seems to be correct that $\chi \alpha \rho \iota \zeta{ }^{\prime} \mu \varepsilon v o l$ has the specific nuance in this case of 'forgiving'. Louw and Nida (eds.

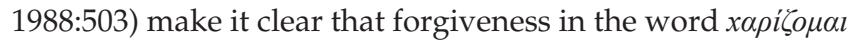
has a specific attitude going with it - an attitude of 'grace' towards the person to forgive. O'Brien (1999:351) says it emphasises the gracious nature of the pardon. This forgiveness thus needs to grow out of a feeling of grace towards the person.

When one forgives, it must mean that one gets rid of the intense resentment, hate, and anger that lead to outbursts, violent anger, screaming, and blasphemy. Klein et al. (2006) refer to the inner to outer progression in this list of sins. The bitterness $(\pi \imath \kappa \rho i \alpha)$ is an inner feeling, generating anger $(\theta v \mu \grave{s} \varsigma)$, leading to emotional outbursts ( $\dot{\rho} \gamma \gamma \dot{\eta})$, leading to verbal outbursts and screaming and quarrelling ( $\kappa \rho \alpha v \gamma \grave{\eta})$, leading to blasphemy $(\beta \lambda \alpha \sigma \varphi \eta \mu i \alpha)$ - abusive speech that denigrates, defames or slanders. Unforgiveness thus leads to a feeling of bitterness, causes anger, leads to emotional outbursts, causing quarrels and screaming, leading to abusive speech. The inner feeling of bitterness should thus be replaced by the inner feeling of kindness (Bray 2011:363). When bitterness disappears, one can remember the past without experiencing the pain (Van der Merwe 2017:163-165). Without this forgiveness, relationships cannot work and living one's life in love is not possible. Without forgiveness one can hardly be an imitator of God or act wisely.

We need to take note, however, of the instances in which the author addresses the issues of 'forgiveness' and 'grace' in this letter. In the first argument in the letter-body-opening (2:1-10) about sinfulness and salvation, the author refers three times to the 'grace' of God in 2:5 ( $\chi \dot{\alpha} \rho \imath \imath i)$, 2:7 ( $\tau, \chi \alpha \dot{\alpha} \rho \imath \tau o \varsigma)$, and 2:8 ( $\chi \dot{\alpha} \rho \imath \tau i)$. In the third argument in 3:1-13 of the letterbody-opening, where the author introduces himself as a preacher to the Gentiles, he refers to God's grace, given to him. In the doxology in 1:3-14, the author already praises God for his 'grace' ( $\tau(a$ xó $\rho \imath \tau o \varsigma \alpha \dot{v} \alpha \rho)$ ), and refers to the 'forgiveness' of sins through Christ in 1:7 ( $\tau$ of öof si $\tau \tau f$ $\pi \alpha \rho \alpha \pi \tau \omega \mu \alpha \dot{\alpha} \omega v)$ in accordance with the riches of God's

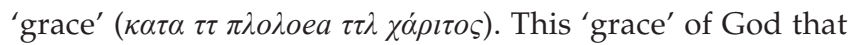
we also find in the root of the $\chi \alpha \rho \imath \zeta{ }^{\prime} \mu \varepsilon v o r$ in 4:32, has the meaning possibilities of 'kindness' (eds. Louw \& Nida 1988:749), 'a gracious gift' (eds Louw \& Nida 1988:569), and 'goodwill' (eds. Louw \& Nida 1988:299). The noun ö299). describes the forgiveness of the guilt resulting from the wrongdoing (eds. Louw \& Nida 1988:503). Although ö503). is used in this instance and not $x \alpha \rho i \zeta o \mu \alpha l$, the forgiveness of sins ( $\tau t \ddot{\alpha}$ the $\tau \tau t \pi \alpha \rho \alpha \pi \tau \omega \mu \alpha \dot{\alpha} \omega v$ ) in 1:7 is directly connected to the grace of God when it is said that the forgiveness is 'in

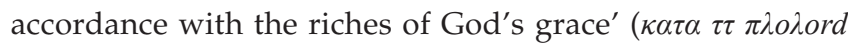
$\tau \tau \lambda \chi \alpha \dot{\alpha}(\tau o \varsigma)$. Forgiveness and grace are thus connected in the structure of this sentence, even though the word $\ddot{\alpha}$. For is used. Ephesians is clear about the attitude of forgiveness that it cannot happen without grace. When the author exhorts his readers to forgive, he does not use the verb ait $c a$ like the noun oxlike was used in 1:7. He chooses to use the verb $\chi \alpha \rho i \zeta o \mu \alpha l$ - adding a specific attitude to this action. The grace and the forgiveness in 4:32 in Ephesians cannot be separated. The command is not to be demanding when you forgive - it is an act coming from one's grace, kindness, compassion - it is a gift coming from oneself. The fact that $\chi \alpha \rho \imath \zeta o ́ \mu \varepsilon v o l$ is in the present tense, made O'Brien (1999:351) say that it is an indication that forgiveness is to be 'unceasing' and 'unwearying' - most probably because he considers the present tense to indicate a continuous action. Funk does not really offer this as a typical meaning of the present participle, although he (Funk 1961:175) does give an example at one point of a present participle being translated with an action happening continuously.

The participle $\chi \alpha \rho \imath \zeta o$ $\mu \varepsilon v o r$ is also elaborated on with the

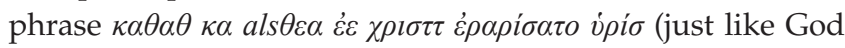
forgave you in Christ). Once again, the verb $\chi \alpha \rho i \zeta o \mu \alpha l$ is used. This particular verb $\chi \alpha \rho i \zeta o \mu \alpha l$ is not often used in the New Testament to denote the meaning of forgiveness. The only instances where it does mean 'forgiveness', are found in the following passages:

- 2 Corinthians 2:7 'with the result to rather forgive' $(\chi \alpha \rho i \sigma \alpha \sigma \theta \alpha \imath)$

- 2 Corinthians 2:10 'if you forgive ( $\chi \alpha \rho i \zeta \varepsilon \sigma \theta \varepsilon)$ him, so will I...'

- 2 Corinthians 12:13 '... Forgive ( $\chi \alpha \rho i \sigma \alpha \sigma \theta \varepsilon \dot{)})$ me this wrong!'

- Colossians 2:13 'God made you alive... by forgiving

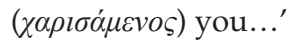

- Colossians 3:13 '... by forgiving ( $\alpha \alpha \rho \zeta$ ¿́ $\mu \varepsilon v o \imath$ ) each other... as the Lord forgave ('ं $\chi \alpha \rho i \sigma \alpha \tau o)$ you'.

In 2 Corinthians three examples are found where a form of $\chi \alpha \rho i \zeta o \mu \alpha l$ is used to indicate that people should forgive (1 Cor $2: 7 ; 2: 10 ; 12: 13)$. In Colossians two examples are found where forms of $\chi \alpha \rho i \zeta o \mu \alpha l$ are used to communicate that God forgave people (Col 2:13 and 3:13b), and that believers should forgive 
TABLE 2: Comparison between Ephesians 4:32 and Colossians 3:12-13.

\begin{tabular}{|c|c|}
\hline Ephesians 4:32 & Colossians 3:12-13 \\
\hline 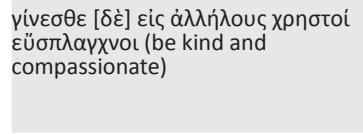 & 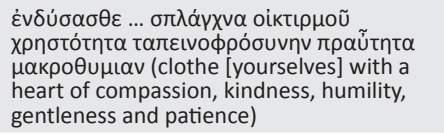 \\
\hline 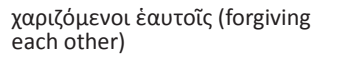 & 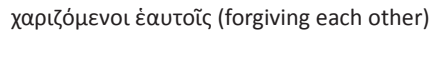 \\
\hline 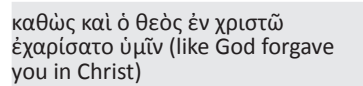 & 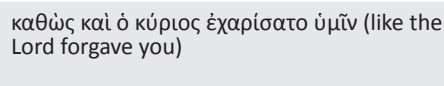 \\
\hline
\end{tabular}

(Col 3:13a). Colossians 3:13 seems to be very similar to what is found in Ephesians 4:32, as shown in Table 2.

These thoughts about forgiveness appear in both letters in arguments on 'living a holy life' (Colossians) and 'living as children of the Light' (Ephesians).

The author exhorts his readers to 'behave in the same gracious manner that God did in His Son' (Hoehner 2002:640). God's gracious act in Jesus thus serves as the model for the readers, and his grace is discussed earlier on in the letter in 1:7-12 and 2:4-10. Klein et al. (2006) say it is clear that God is the standard for this imperative to be kind and compassionate. The author of Ephesians not only uses the persuasion strategy of logos -logical reasoning - in this verse, but also the strategy of pathos ${ }^{13}$ to emotionally affect the readers to feel inclined to follow this standard and example. The readers must be motivated by God's incredible generosity in granting his people complete forgiveness. Van der Merwe (2017:163) says the exhortation is to extend God's forgiveness of us, to our forgiveness of others. Jones (1995:xii) says God's forgiveness in Christ is the context for forgiveness - he (Jones 1995:4) says that forgiveness requires the believer's death, a participation 'in Christ's dying and rising', the death of the old self and the beginning of a new future that is not bound by the past. This makes total sense in the light of Ephesians 4:22-24 - to put off the old self, to be made new in your minds and to put on the new self. Forgiveness is not simply 'a word spoken, an action performed, or a feeling felt' (see Jones 1995:xii). God's forgiveness in Christ involved a high cost as it required Jesus to suffer, die, and rise again. This means that forgiveness is a life-long process of learning the craft of transforming one's life and relationships (see Jones 1995:xiii). It is a forgiveness for one's own sake - to get rid of bitterness, to restore one's relationship with God, and to help heal society.

How can this forgiveness become a reality in believers' lives? By making a decision not to live like the Gentiles in darkness, but by changing the attitude of one's mind.

\section{Psychology's opinion about anger, bitterness and forgiveness}

A painful experience caused by another party, can not only motivate people 'to avoid personal and psychological contact' with that party, but it can also motivate people 'to seek revenge' (see McCullough et al. 1998:1587). How is such

13.See Aristotle (1947), Ars Rhetorica 1, 2:3-6 for a discussion of these persuasion strategies. an unforgiving response to pain seen by psychologists? Witvliet, Ludwig and Vander Laan (2001:118) consider an unforgiving response to be health-eroding through a constant rehearsing of memories of the painful experience, harbouring and nursing a grudge against those who were responsible for the hurt, staying in the victim role and perpetuating negative emotions associated with this rehearsing, and committing oneself to remain angry (see Witvliet et al. 2001:118).

A forgiving response involves a transformation that 'inclines people to inhibit relationship destructive responses and to behave constructively toward someone who had behaved destructively toward them' (McCullough, Worthington \& Rachal 1997:321). To forgive one's offender is to choose to abandon one's right to resentment and retaliation, and to instead offer mercy to one's offender (see Enright \& Coyle 1998:140). Enright and Coyle (1998:142) explain that genuine forgiveness is 'voluntary and unconditional', that it is 'not dependent on the apology or recognition of wrongdoing on the part of the offender'. Forgiving thus involves 'change' - a cognitive, emotional and behavioural change (Witvliet 2001:118).

How would psychologists understand the 'change of mind', and the 'adoption of a new attitude in one's mind' as found in Ephesians 4:23 - the reason for the exhortations to live a new life in the Light of God? Shapiro (2020) published her book with the title Rewire Your Mind, and this title makes

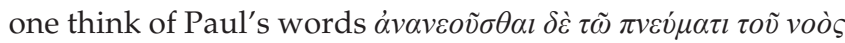
$\dot{v} \mu \tilde{\omega} v$ 4:23 - to be made new in the attitude of your mind. How does one rewire one's mind - one's attitude and thinking? Shapiro (2020) explains that this process of rewiring one's mind is a transformation in which we:

[I]ntegrate new ways of thinking, feeling, and behaving as we lay down new pathways in our brain and then let these pathways express themselves in our thoughts, words and actions. (p. 29)

McCullough et al. (1998:1587) describe the first steps in this process into change as judgements of responsibility and blame, perceived intentionality, severity, avoidability of offense' and a 'rumination about the offense'. Shapiro (2020:37) calls it 'mindfulness' - 'clear comprehension' which helps us to 'see clearly, so we can make wise choices and respond to life effectively'. This mindfulness, Shapiro (2020:38) proceeds, 'frees us from past conditioning and habitual patterns', 'it helps us remove the filters, biases, and preconceived ideas that shape our perceptions and cloud our consciousness'. The logic behind it all is that once one sees clearly, one can respond effectively (Shapiro 2020:38). Paul says in Ephesians 4:22 and 24 that through rewiring one's mind, one will be able to put on a new self and put off the old self. Shapiro (2020:49) quotes Barbara de Angelis who says that the first step is to shift one's consciousness, in order to improve the quality of one's thoughts and emotions, in order to improve the quality of one's choices, in order to improve the quality of one's life. Paul says in Ephesians 4:17: 'you can no longer live as the Gentiles do' because you were taught (4:17) to rewire your mind (4:23). 
The result of rewiring one's mind should, according to Ephesians 4:25-32; 5:3-7 result in better behaviour. This includes forgiveness (4:32). Can we see the behaviour mentioned in Ephesians 4:31 being avoided as the opposite of the kindness and compassion that comes through forgiveness in verse 32 ? Verse 31 exhorts the readers to avoid bitterness $(\pi \imath \kappa \rho i \alpha)$, rage $(\theta v \mu \grave{s} \varsigma)$, anger $(\dot{o} \rho \gamma \dot{\eta})$, screaming $(\kappa \rho \alpha v \gamma \grave{\eta})$, and abusive speech $(\beta \lambda \alpha \sigma \varphi \eta \mu i \alpha)$. It seems fair to say that rage, screaming, and abusive speech are all ways to deal with anger - a way to release the anger (see Baumeister et al. 2018:178-179). This anger, Baumeister et al. (2018:177) say can be defined as an 'emotional response to a threat or provocation' and it can 'range in intensity from mild irritation to extreme rage'. From Ephesians it seems as if the anger and these outlets of anger are dangerous for relationships. Where does the bitterness fit in? Is anger a result of bitterness? Seltzer (2015) is of the opinion that 'anger matures into bitterness' - thus the other way around. According to Seltzer (2015) anger and resentment are the emotions caused by hurt, maturing into 'the corrosive ulcer' of bitterness. Diamond (2009) defines this bitterness as one of the most toxic and destructive of human emotions - 'a chronic and pervasive state of smouldering resentment'.

In psychological circles, anger is not only seen as a negative emotion, but also as a helpful signal for what to avoid and when to withdraw. In this sense, Baumeister et al. (2018:177) explain that anger can be a 'powerful force in helping people to stand up for what they believe is right'. Although anger can result in abusive speech or screaming or a total rage, it can be a normal emotion that can help people survive. Anger (caused by something that happened in the present) can lead to an outburst that can hurt people, but it is not always bad and can eventually pass and lead to positive results. The danger is, however, when this kind of anger 'matures' into bitterness, when it becomes a silent, inner hate and resentment, latching onto the person who cannot let go of it. Bitterness is when people hold on to bitter emotions and continuously dwell in the past. Holding on to bitterness is a choice not to forgive.

Now it seems that the author of Ephesians was indeed presenting two sides of a coin - bitterness versus forgiveness. What is forgiveness? Forgiveness is what will repair the bitter person's life, leading him or her out of the darkness into the light. Shapiro $(2020: 117)$ is of the opinion that forgiveness is the most challenging thing to do and also the most transformational.

It is no wonder that Mahatma Gandhi once said that the weak can never forgive - that forgiveness is an attribute of the strong. Forgiveness is not about simply moving on or letting go. It is a deliberate decision to let go of emotions and attitude towards an offender (Baumeister et al. 2018:182), a deliberate choice to let go of bitterness - a difficult process which eventually will result in psychological well-being and health, in kindness and compassion and restore relationships. McCullough et al. (1997:321-322) define interpersonal forgiving as changes whereby one becomes less motivated to offend the person who once hurt one, less motivated to be estranged from the offender, more motivated by conciliation and goodwill for the offender - it is thus a total transformation where bitterness diminishes. When bitterness diminishes, it seems as if goodwill and reconciliation step forward. McCullough et al. (1997:322) hypothesise that 'empathy for the offending partner is the central facilitative condition that leads to forgiving'. Empathy, they explain, incorporates sympathy, compassion, and tenderness.

Ephesians 4:32 exhorts the readers rather to be kind ( $\chi \rho \eta \sigma \tau o i)$ and compassionate ( $\varepsilon \dot{v} \sigma \pi \lambda \alpha \gamma \chi v o r)$, while forgiving each other

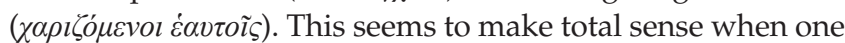
consults psychologists on the logic behind forgiveness. The bitterness, as a result of unfinished anger, destroys relationships while kindness and compassion that are possible through forgiveness, can save relationships. Rewiring one's mind - a mindfulness - Shapiro (2020:62) claims, involves 'bringing a kind and curious attitude to whatever we are experiencing'. Shapiro (2020:117-118) says that forgiveness requires us to integrate the following skills: 'acceptance, emotion regulation, shifting perspectives, compassion, and radical responsibility'. This is what Paul exhorts in 4:32: 'be kind and compassionate, when you forgive'. Forgiveness implies compassion for oneself and for others. This compassion, Shapiro (2020:77) claims, 'is born of mindfulness', of rewiring one's mind.

Why would Paul think that forgiveness would improve the relationships and lives of his readers? Shapiro $(2020: 118,126)$ says that forgiveness reduces one's own suffering and it brings greater dignity and harmony and peace to one's life, and it magnifies life's joy because it frees one from the past, it opens the future. Studies have also proven that forgiveness improves one's physical health (See Carson et al. 2005:84-91; Lawler et al. 2003:373-393; Witvliet 2001:212-224). One can understand that a healthy, happy, and peaceful individual brings a positive energy to relationships so that it will benefit humankind.

Shapiro's (2020:68) warning, however, that mindfulness is not about creating or changing anything about one's experience, should be kept in mind. Mindfulness, Shapiro (2020:68) explains, is changing the way one relates to experiences. The change does not depend on rearranging things on the outside of one's life, but on the inside (De Angelis 2016:65).

Staub and Pearlman's (2001:206) comment is a warning relevant to South Africans: healing is necessary in South Africa not only to improve the quality of life for South Africans, but also to make it less likely that South Africa becomes a perpetrator country of violence. It is clear that in South Africa, the danger is that different groups have victimised one another and, therefore, Staub and Pearlman's (2001:206) opinion is a warning for South Africans: 'when there has been mutual victimization by' different 'groups, if the groups continue to live near each other, reconciliation is 
essential both to stop a potentially continuing cycle of violence and to facilitate healing'.

\section{The possible power of forgiveness in a broken South Africa}

Forster (2020:56) reports that: 'South Africa remains a deeply religious nation with almost $85 \%$ of the population selfidentifying as members of the Christian faith'. Therefore, Forster states that religion plays an important role in shaping social and political ideas in South Africa. This report made the researcher take the first step to think that forgiveness is indeed possible in South Africa as $85 \%$ of the South African population (being members of the Christian faith) can all be persuaded of the Christian view of forgiveness in the Bible. This is most probably one of the reasons why Vorster (2009:379) says that the church should be actively involved in the promotion of a spirit of repentance and forgiveness.

Forster (2020:61) does, however, also point to the proven fact that many in South Africa have a culturally and socially informed biblical hermeneutics when it comes to an understanding of forgiveness. He referred to a study that proved that for white South Africans, forgiveness is a spiritual matter. For black South Africans, forgiveness has a transactional nature. That is why, in the discourse of transformation and reconciliation, black South Africans use nouns like 'acts of change', 'restitution', 'remorse', and 'expectation for compensation and redistribution' (see Forster 2020:57). The two groups of South Africans have different ethics (Forster 2020:57-60). One group has an ethic of mercy, striving for social harmony, national cohesion, and a lack of racial enmity. The other group has an ethic of responsibility, striving for economic transformation, transfer of land ownership, and transformation of social power dynamics. The different ethics, however, prove that the church has a responsibility to proclaim forgiveness as it is exhorted in the Bible and to inform members of the Christian communities of a responsible, biblical hermeneutic.

The church needs to show South Africans what forgiveness is according to the Bible and what the advantages of forgiveness can be for the individual as well as for the society. The list of vices to be avoided according to Paul in Ephesians 4:31, seems to picture the situation in a broken South Africa: bitterness, rage, anger, screaming, and abusive speech. Ephesians 4:23 demands a change in the nature of people's minds in order to be able to, inter alia, be kind and compassionate when they forgive each other. This forgiveness means to take control as a believer, to use one's power as a Christian - without being dependent on others - and to forgive because God forgave us. We need to be the initiators of the transaction. Forgiveness is not about whether or not our offenders are worthy of forgiveness. We forgive for our own sake and this forgiveness is a 'means for imitating God', for 'carrying out God's plan', and 'enhancing one's relationship' with God (see Rye et al. 2000:17).
This kind of forgiveness is a choice and it will restore relations and has social advantages. Forgiveness is a gift to oneself and to others, to society, and to one's country. Nobody can take one's power to forgive.

How can forgiveness save South Africa? Apartheid caused painful experiences for many South Africans who had to suffer for a long time, not only during apartheid, but even after the era of apartheid, as the consequences of the legacy of apartheid that lingered on for many years thereafter. This caused many South Africans to react in a new South Africa where the whites no longer dominate, with an unforgiving response, creating more pain, leading to more unforgiving responses to these reactions.

Ephesians advises to no longer rehearse memories of pain, to stop harbouring and nursing grudges, to stop playing the victim role and perpetuating negative emotions associated with this rehearsing, and to break their commitment to remain angry (see Witvliet et al. 2001:118). Ephesians makes South Africans aware of the need and the power of rewiring one's mind in order to forgive from a gracious heart. This forgiveness does not imply 'denying, ignoring, minimizing, tolerating, condoning, excusing, or forgetting' the offenses of the past (see Enright \& Coyle 1998:141), but a new thinking about it.

If South Africans want a better future, they need to realise that forgiveness will improve the psychological well-being of individual South Africans, that it will lift the burdens of anger and the desire for revenge (see Staub \& Pearlman 2001:207). If this will not happen, the danger of violence will be ever present in South Africa and South Africans will never be able to call out 'ubuntu', because we are in a situation of mutual violence where the original victims become the perpetrators - a vicious cycle that will repeat the pain and anger. We as South Africans need to accept the past and to not allow the past to define our future.

What is the role of the church in all of this? Van der Merwe (2017:168-169) says that the church needs to take the lead and reach out, provide Biblical education, set the example, engage in dialogue about racism, and organise workshops and activities to promote mutual respect. The church thus needs to move to the frontline, and guide political leaders.

\section{Conclusion}

Does Ephesians persuade readers that repentance is a prerequisite for forgiveness, or does it persuade readers that forgiveness should be separated from justice (see Jones 1995:xi)? Ephesians aims to persuade believers that forgiveness is a choice to imitate God. Forgiveness is an act out of grace, kindness, and compassion.

\section{Acknowledgements Competing interests}

The author declares that she has no financial or personal relationships that may have inappropriately influenced her in writing this article. 


\section{Author's contributions}

E.C. is the sole author of this article.

\section{Ethical considerations}

This article followed all ethical standards for research without direct contact with human or animal subjects.

\section{Funding information}

This research received no specific grant from any funding agency in the public, commercial or not-for-profit sectors.

\section{Data availability}

Data sharing is not applicable to this article as no new data were created or analysed in this study.

\section{Disclaimer}

The views and opinions expressed in this article are those of the author and do not necessarily reflect the official policy or position of any affiliated agency of the author.

\section{References}

Aland, B., Aland, K., Karavidopoulos, J., Martini, C.M. \& Metzger, B.M. (eds.), 1994 The Greek New Testament, 4th rev. edn., Deutsche Bibelgesellschaft United Bible Societies, Stuttgart.

Aristotle, 1947, Ars Rhetorica, Loeb Classical Library, William Heinemann, London.

Baumeister, R.F., Bushman, B.J., De Sousa, Y.A., Dhlomo-Sibiya, R.M., Hermann, C., Mbatha, K. et al., 2018, Social psychology, Cengage, Boston, MA.

Baxter, J., 2020, Latest crime statistics for South Africa: Increase in murder rate, viewed 21 December 2020, from https://www.sapeople.com/2020/07/31/latestcrime-statistics-for-south-africa-increase-in-murder-rate/.

Bray, G.L., 2011, Galatians, Ephesians, reformation commentary on scripture, New Testament, volume 10, InterVarsity Press, Downers Grove, IL.

Carson, J.W., Keefe, F.J., Goli, V., Fras, A.M., Lynch, T.R., Thorp, S.R. et al., 2005, 'Forgiveness and chronic low back pain: A preliminary study examining the
relationship of forgiven ess to pain, anger, and psychological distress', Journal of relationship of forgiven ess to pain, anger, and psychological
Pain 6(2), 84-91. https://doi.org/10.1016/j.jpain.2004.10.012

Cohick, L.H., 2005, Ephesians: A New Covenant commentary, Cascade Books, Eugene, OR.

Conradie, P., Cronje, K., Janse van Rensburg, F.J., Olivier, W., Swart, G. \& Wolmarans, H. (eds.), 1999, Grieks met begrip: 'n Inleidende grammatika, toegespits op die Griekse Nuwe Testament, Wetenskaplike bydraes van die PU vir CHO, Reeks DSP:21, PU vir CHO, Potchefstroom.

Corporate Communication, 2017, Is forgiveness really possible in South Africa? viewed 15 October 2020, from www.sun.ac.za/english/Lists/news/DispForm. aspx?ID=5156.

De Angelis, B., 2016, Soul shifts: Transformative wisdom for creating a life of authentic awakening, emotional freedom, and practical spirituality, Hay House, Carlsbad, CA.

Diamond, S., 2009, Anger disorder (part two): Can bitterness become a mental disorder?, Psychology Today, Sussex Publishers, viewed 01 January 2021, from www.psychologytoday.com/blog/evil-deeds/200906/anger-disorder-part-twocan-bitterness-become-mental-disorder.

Enright, R.D. \& Coyle, C.T., 1998, 'Researching the process model of forgiveness within psychological interventions', in E.L Worthington, Jr. (ed.), Dimensions of forgiveness, pp. 139-161, Templeton Foundation Press, Philadelphia, PA.

Forster, D.A., 2020, 'Towards an (im)possible politics of forgiveness: Considering the complexities of religion, race and politics in South Africa', in M.J. Nel, D.A. Forster \& C.H. Thesnaar (eds.), Reconciliation, forgiveness and violence in Africa: Biblical, pastoral and ethical perspectives, pp. 51-69, SUN Press, Stellenbosch.
Fowl, S.E., 2012, Ephesians: A commentary, Westminster John Knox, Louisville, KY.

Funk, R.W., 1961, A Greek grammar of the New Testament and other early Christian lieterature, transl. F. Blass \& A. Debrunner and rev. 9th-10th German edn., The University of Chicago Press, Chicago, IL.

Gibson, D., 2020, SA's murder rate is worse than the coronavirus mortality rate, viewed 15 October 2020, from https://www.iol.co.za/news/opinion/sas-murderrate-is-worse-than-the-coronavirus-mortality-rate-43987823.

Gundry, R.H., 2012, A survey of the New Testament, Zondervan, Grand Rapids, MI.

Hoehner, H.W., 2002, Ephesians - An exegetical commentary, Baker Academic, Grand Rapids, MI.

Jones, L.G., 1995, Embodying forgiveness: A theological analysis, William B. Eerdmans, Grand Rapids, MI.

Klein, W.W., Garland, D.E., Still, T.D. \& Rupprecht, A.A., 2006, Ephesians, Philippians, Colossians, Philemon, Zondervan, Grand Rapids, MI.

Lawler, K.A., Younger, J.W., Piferi, R.L., Billington, E., Jobe, R., Edmondson, K. et al., 2003, 'A change of heart: Cardiovascular correlates of forgiveness in response to interpersonal conflict', Journal of Behavioral Medicine 26(5), 373-393. https:// doi.org/10.1023/A:1025771716686

Louw, J.P. \& Nida, E.A. (eds.), 1988, Greek-English Lexicon of the New Testament, United Bible Societies, New York, NY.

Mc Cullough, M.E., Pargament, K.I. \& Thoresen, C.E. (eds.), 2000, Forgiveness: Theory, research and practice, The Guilford Press, New York, NY.

Mc Cullough, M.E., Rachal, K., Sandage, S.J., Worthington, E.L., Brown, S.W. \& Hight, T.L., 1998, 'Interpersonal forgiving in close relationships: II: Theoretical elaboration and measurement', Journal of Personality \& Social Psychology 75(6), 1586-1603. https://doi.org/10.1037/0022-3514.75.6.1586

Mc Cullough, M.E., Worthington, E.L. Jr., \& Rachal, K.C., 1997, 'Interpersonal forgiving in close relationships', Journal of Personality and Social Psychology 73(2), 321-336. https://doi.org/10.1037/0022-3514.73.2.321

Moulton, H.K., 1978, The analytical Greek Lexicon revised, Regency, Grand Rapids, MI.

Msimang, S., 2018, All is not forgiven: South Africa and the scars of apartheid, viewed 15 October 2020, from https://www.foreignaffairs.com/articles/south africa/2017-12-12/all-not-forgiven.

Nkosi, M., 2018, 'Winnie Mandela - The young mother who refused to be broken', $B B C$ News, viewed 14 February 2021, from https://www.bbc.com/news/worldafrica-43630442.

O'Brien, P.T., 1999, The letter to the Ephesians, William B. Eerdmans, Grand Rapids, MI.

Rye, M.S., Pargament, K.I., Ali, M.A., Beck, G.L., Dorff, E.N., Hallisey, C. et al., 2000, 'Religious perspectives on forgiveness', in M.E. McCullough, K.I. Pargament \& C.E. Thoresen (eds.), Forgiveness: Theory, research and practice, pp. 17-40, Guilford, New York, NY.

Seltzer, L.F., 2015, 'Don't let your anger "mature" into bitterness', Psychology Today, viewed 15 February 2021, from https://www.psychologytoday.com/us/blog/ evolution-the-self/201501/don-t-let-your-anger-mature-bitterness.

Shapiro, S., 2020, Rewire your mind: Discover the sciences and practice of mindfulness, Octopus Books, London.

South African Government News Agency, 2010, 'SA's violent crime has roots in apartheid, says report', SA News, viewed 15 October 2020, from https://www. sanews.gov.za/features/sas-violent-crime-has-roots-apartheid-says-report.

Staub, E. \& Pearlman, L.A., 2001, 'Healing, reconciliation, and forgiving after genocide and other collective violence', in R.G. Helmick \& R.L. Petersen (eds.), Forgiveness and reconciliation: Religion, public policy and conflict transformation, pp. 205-227, Templeton, Philadelphia, PA.

Swindoll, C.R., 2015, Galatians, Ephesians, Tyndale House, Carol Stream, IL.

The Globalist, 2018, South Africa's violent crime problem, viewed 15 October 2020, from https://www.theglobalist.com/south-africa-violent-crime-apartheid/.

Van der Merwe, D., 2017, 'Christianity at war with racism', in J.A. Du Rand, J.M. Vorster \& N. Vorster (eds.), Togetherness in South Africa, Religious perspectives on racism, xenophobia and economic inequality, pp. 137-168, AOSIS, Cape Town.

Vorster, J.M., 2009, 'An ethics of forgiveness', Verbum et Ecclesia JRG 30(1), 365-383. https://doi.org/10.4102/ve.v30i1.79

Witvliet, C.V., 2001, 'Forgiveness and health: Review and reflections on a matter of faith, feelings and physiology', Journal of Psychology and Theology 29(3), 212-224. https://doi.org/10.1177/009164710102900303

Witvliet, C.V.O., Ludwig, T.E., \& Vander Laan, K. L., 2001, 'Granting forgiveness of harboring grudges: Implications for emotion, physiology, and health', Psychological Science 12(2), 117-123. https://doi.org/10.1111/1467-9280.00320

Zulu, A., 2020, Farm murders and the lie of white victimhood, viewed 14 December 2020, from https://thoughtleader.co.za/farm-murders-and-the-lieof-white-victimhood/. 